\title{
Formulation, in vitro Characterization and Stability Studies of Fast Dispersing Tablets of Diclofenac Sodium
}

\author{
Ranjit Prasad Swain*, R. Nagamani, Satyajit Panda \\ ${ }^{1}$ Department of Pharmaceutical Technology, Maharajah`s College of Pharmacy, Vizianagaram, A. P., India.
}

\begin{tabular}{|c|c|}
\hline ARTICLE INFO & ABSTRACT \\
\hline $\begin{array}{l}\text { Article history: } \\
\text { Received on: } 03 / 03 / 2015 \\
\text { Revised on: } 18 / 04 / 2015 \\
\text { Accepted on: } 06 / 06 / 2015 \\
\text { Available online: } 27 / 07 / 2015\end{array}$ & $\begin{array}{l}\text { The present study was aimed to formulate, develop and evaluate the fast dissolving tablets of diclofenac sodium, } \\
\text { used for the treatment of arthritis, inflammation, pain. Fast dissolving tablets of diclofenac sodium were prepared } \\
\text { by direct compression method using crospovidone and sodium starch glycolate as superdisintegrants in } \\
\text { concentrations of } 5.3 \%, 6.6 \% \text { and } 8 \% \mathrm{w} / \mathrm{w} \text { and in combination. In this work microcrystalline cellulose and } \\
\text { mannitol are investigated as diluents. Prepared powder mixtures were evaluated for drug excipient compatibility }\end{array}$ \\
\hline $\begin{array}{l}\text { Key words: } \\
\text { Fast dissolving tablets, } \\
\text { diclofenac sodium, } \\
\text { crospovidone, sodium starch } \\
\text { glycolate. }\end{array}$ & $\begin{array}{l}\text { disintegration dispersion and wetting time. Formulation FCS6 prepared with combination of crospovidone and } \\
\text { sodium starch glycolate at weight ratio of } 6.6 \text { and } 2.3 \% \text { showed better results compare with control. Post } \\
\text { compression parameters like hardness }\left(3.4 \mathrm{~kg} / \mathrm{cm}^{2}\right) \text { and friability }(0.31 \%) \text { are at good acceptable levels in } \\
\text { accordance with official compendia. FCS6 showed improved dissolution }(99.8 \%) \text { and dispersion }(75 \text { seconds) } \\
\text { profiles compared to control. The FTIR and DSC showed no interaction between the drug and excipients. The } \\
\text { optimized formula FCS6 showed good drug release characteristics with acceptable mouth feel and fast dissolving } \\
\text { properties. }\end{array}$ \\
\hline
\end{tabular}

\section{INTRODUCTION}

Oral drug delivery has been known for decades as the most widely utilized route of administration among all the routes due to its ease of administration, cost-effectiveness and flexibility in design (Agarwal and Mishra, 1999). About $60 \%$ of all dosage forms available are the oral solid dosage forms (Chein, 1992). Recent developments in technology have presented viable dosage alternatives for pediatrics, geriatrics, bedridden, nauseous or noncompliant patients (parkinson, migraine, epilepsy and schizophrenia patient), who face difficulty in swallowing or chewing solid dosage forms and are unwilling to take solid preparations due to a fear of choking. Hence, orodispersible tablets (ODTs) are an ideal dosage form for them. Around $35 \%$ of general population as well as additional $30-40 \%$ of elderly institutionalized patients and $18-22 \%$ of persons in long term facilities have difficulty in swallowing (Avery and Dellarosa 1994; Lindgren and Janzon, 1993).

\footnotetext{
* Corresponding Author

Ranjit Prasad Swain, Department of Pharmaceutical Technology, Maharajah 's College of Pharmacy, Vizianagaram, A. P., India.

Email: ranjit.prasad797@gmail.com
}

US food and drug administration, Center for Drug Evaluation and Research (CDER) defines, in the Orange book. "an ODT as "a solid dosage form containing medicinal substances, which disintegrates rapidly, usually within a matter of seconds , when placed upon tongue".

European pharmacopeia adopted the term orodispersible tablet for a tablet that disperses or disintegrates in less than 3 minutes in the mouth before swallowing. Fast disintegrating tablets (FDTs) disintegrates into smaller granules or melts in the mouth from a hard solid to a gel-like structure, allowing easy swallowing by patients. The disintegration time for good FDTs varies from several seconds to about a minute (USFDA 2003, Pharmaeuropa 1998).

The Fast disintegrating drug delivery systems were first developed in the late 1970 s as an alternative to tablets, capsules, syrups for pediatric and geriatric patients who experience difficulties in swallowing traditional oral-solid dosage forms.

The FDT is also known as fast melting, fast dispersing, rapid dissolve, rapid melt, and /or quick disintegrating tablet. Rapidly dissolving tablets are applicable when local action in mouth is desirable such as local anesthetic for toothaches, oral ulcers, cold sores, or teething (Chang et al., 2000). 
The FDT technologies that make tablets disintegrate in mouth without chewing and additional water intake has drawn a great deal of attention (Alhusban and Mohammed, 2011). Many reported techniques such as polymer coating, microencapsulation, use of lecithins and related substances, liposomes and various polymeric materials mask the bitterness by controlling drug release at salivary $\mathrm{pH}$. So, it was a major challenge to develop taste masked rapidly disintegrating agents with improved drug release (Harmik et al., 2004). FDTs should disintegrate in mouth without additional water or with a very less amount of water provided by saliva as disintegration medium. Disintegrated tablet should become a soft paste or suspension which can provide good mouth feel and smooth swallowing. The "fast disintegration" usually means disintegration of tablets in less than 1 minute, but it is preferred to have disintegration as soon as possible (Chang et al., 2000). ODTs have better patient acceptance, compliance, offer improved biopharmaceutical properties, efficacy, and increased bioavailability compared with conventional oral dosage (Indurwade et al., 2002). The hardness of the products was not enough to stand the process of packaging and transportation. Therefore, direct compression is the simplest, most convenient and easiest way to produce rapidly disintegrating tablets with sufficient structural integrity. Superdisintegrants should not only produce stronger tablets but also, disintegrate the tablet in the oral cavity in less than 30 seconds and increase the dissolution characteristics thus increasing the bioavailability of drug (Koushik et al., 2014). The development of fast dissolving dosage forms as a bioequivalent line of extension to well established marketed products is an effective way for survival and extension of market value for pharmaceutical industry undeserving the patient needs. Utilizing this effective strategy Eisai Inc. launched Aricept ODT, a line extension of donepezil for Alzheimer's disease, in Japan in 2004 and in U.S in 2005 (Harmon, 2014). Today, many FDTs have poor mechanical properties, and require protection in the form of specialized packaging such as ZYDIS blister peel back packing (Kearny, 2002).

Diclofenac, a phenyl-acetic acid derivative, (Fig. 1) is a non-steroidal anti-inflammatory drug (NSAID) with analgesic anti-pyretic properties. It is used mainly as the sodium salt for the relief of pain and inflammation in various conditions.

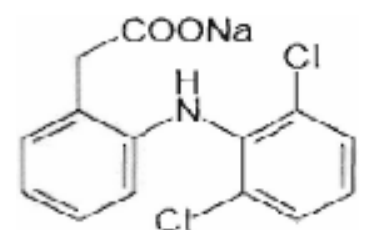

Fig. 1: Structure of Diclofenac sodium.

NSAIDs mainly inhibit the bio synthesis of prostaglandins. These are released whenever the cells are damaged. They appear in inflammatory exudates (Burke et al., 2006). It inhibits cyclooxygenase 1 and 2 activity, hence reducing the production of prostaglandins and thromboxane associated with pain and inflammation. Diclofenac sodium also reduces the arachidonic acid bioavailability and appears to reduce intracellular concentrations of free arachidonate in leukocytes (Fishman, 2001). It has an unpleasant taste and causes gastric irritation (Sweetman, 2002). The aim of the study was to develop formulations of diclofenac sodium fast dispersing tablets. All the formulations should offer an acceptable disintegration time less than 3 minutes and at the same time and finally to increase dissolution rate, possess sufficient mechanical strength so that they will withstand the course of manufacturer and subsequent packaging. On the basis of these considerations, in the present study it was proposed to formulate an oral delivery system, in the form of fast dispersing tablet of diclofenac sodium using two superdisintegrating agents i.e., crospovidone, sodium starch glycolate and their combinations in different ratios. These are used mainly due to low cost (economic) and high compressible nature. Crospovidone and sodium starch glycolate have been reported to result in rapid volume expansion and hydro static pressures allowing disintegration (Battu et al., 2007). In general sugar alcohols such as mannitol used as diluent because of their easy dissolution in water, sweet in taste and cooling sensation in the oral cavity (Takeuchi et al., 2004). To improve the mechanical strength of these ODTs, researchers have studied directly compressed tablets to post compaction treatment. The developed formulations aimed also to improve its palatability by a close association with a rasp berry (flavoring agent) \& the presence of sweet taste additive as aspartame.

\section{MATERIALS AND METHODS}

\section{Materials}

All materials used in this present research were of commercial samples. Diclofenac sodium (Yarrow chem. Products, Mumbai), Mannitol (Yarrow chem. Products, Mumbai), Crospovidone (Yarrow chem. Products, Mumbai), Microcrystalline cellulose (Chemica- biochemica reagents, Mumbai), Sodium starch glycolate (Yarrow chem. Products, Mumbai), Aspartame (Yarrow chem. Products, Mumbai), Rasp Berry (Virgina Dare, Broklyn, NY 11232), Magnesium Stearate (Yarrow chem. Products, Mumbai), Talc (Yarrow chem. Products, Mumbai). All other chemicals were of analytical reagent grades.

\section{Methods \\ Preparation of tablets}

Fast dispersing tablets of diclofenac sodium were prepared by direct compression method using superdisintegrants according to the formulae given in Table 1. Diclofenac sodium $150 \mathrm{mg}$ tablets containing $50 \mathrm{mg}$ of drug were prepared. In all formulations mannitol and microcrystalline cellulose are used as diluents. The specified quantity of diclofenac sodium and other excipients were accurately weighed and passed through 40\# mesh screen prior to mixing. All the materials were transferred to mortar in a geometrical order and co-grounded for 15 minutes. Later by adding magnesium stearate and talc in required quantities the resulting powder mixture was compressed into tablets by using 
Rimek tablet punching machine MINI PRESS 1 (Karnavathi engineering Pvt. Ltd., Gujarat, India) using $8 \mathrm{~mm}$ flat surface punches. The compression force was adjusted to give tablet hardness in the pharmacopoeia range of ODTs $\left(2-4 \mathrm{~kg} / \mathrm{cm}^{2}\right)$.

\section{Pre-compression evaluation}

\section{Fourier transform infrared spectroscopy (FTIR) study}

IR study of pure drug diclofenac sodium and physical mixtures were performed to find out any possible drug-excipient interaction by $\mathrm{KBr}$ pellet method using (IR prestige 21 Shimadzu Corporation, Japan) spectrophotometer.

\section{Differential scanning calorimeter (DSC) study}

DSC thermogram of pure drug diclofenac sodium, crospovidone, sodium starch glycolate and different physical mixtures were (approximately $5 \mathrm{mg}$ ) scanned by using automatic thermal analyzer (Perkin Elmer, Pyris Diamond, Singapore).

\section{Micromeretics study}

Angle of repose $(\theta)$

The angle of repose of powder blends were determined by the funnel method. Accurately weighed powder blends were taken in a funnel. The height of the funnel was adjusted in such a way that the tip of the funnel just touched the apex of the heap of the powder blends $(2 \mathrm{~cm})$. The powder blends were allowed to flow through the funnel freely onto its surface. The diameter of the powder cone was measured and angle of repose was calculated. (Cooper and Gunn, 1986). Three determinations were performed.
$\tan \theta=\frac{h}{r}$$$
\ldots 1
$$$$
\theta=\tan ^{-1} \frac{h}{r} \quad \ldots 2
$$

Where $h$ is the height of pile, $r$ is the radius of the base of the pile, $\theta$ is the angle of repose.

\section{Bulk density and tapped density}

An accurately weighed quantity of the tablet (W), was carefully poured into the graduated cylinder and the volume $\left(\mathrm{V}_{0}\right)$ was measured. Then the graduated cylinder was closed with lid, set into the density determination apparatus (bulk density) apparatus. The density apparatus was set for 100 taps and after that, the volume $\left(\mathrm{v}_{\mathrm{f}}\right)$ was measured and continued operation till the two consecutive readings were equal. The bulk density was calculated using the formulae.

$$
\begin{aligned}
& \text { Bulk density }(\rho)=\frac{\text { Mass of } \operatorname{powder}(w)}{\text { bulk volume }\left(v_{h}\right)} \\
& \text { Tapped density }(\rho)=\frac{\text { Mass of a powder }(w)}{\text { Tapped } \operatorname{volume}\left(v_{f}\right)}
\end{aligned}
$$

Determinations were carried out in 3 replicates. The mean value of three determinations is considered.

\section{Compressibility index and Hausner's ratio}

Carr's compressibility index or Carr's index (CI) determined the compressibility index of the powder blends. Hausner's ratio (HR) was also determined for each powder blend. Three determinations were done for each formula.

$$
\begin{gathered}
\text { Carr's Consolidation index }=\frac{\text { Tapped density-Fluff density }}{\text { Tapped density }} \times 100 \quad \ldots 5 \\
\text { Hausner's ratio }=\frac{\text { Tapped density }}{\text { Bulk density }} \quad \ldots 6
\end{gathered}
$$

\section{Post-compression evaluation}

Weight variation

Tablet designed to contain a specific amount of drug in a specific amount of tablet formula. The weight of the tablet was made is routinely measured to help ensure that a tablet contains the proper amount of drug. Randomly select ten tablets from each formulated batch and individually weighed. The average weight of the selected tablets was calculated by using an electronic balance (Model-IN 201L EC, INFRA Instruments Pvt. Ltd, Chennai, India). Table 2 represents the weight variation specifications as per the U.S.P. The tablets meets the USP test if no more than 2 tablets are outside the percentage limit and if no tablet differs by more than 2 times the percentage limit.

\section{Hardness}

The hardness of the tablet indicates of its tensile strength and is measured in terms of load/pressure require to crush it when placed on its edge. The hardness has influence on disintegration and dissolution times and is such as a factor that may affect bioavailabilities. Monsanto hardness tester is used for measured the hardness of the formulated tablets. It is expressed in $\mathrm{kg} / \mathrm{cm}^{2}$.

\section{Friability}

Friability refers to loss in weight of tablets in the containers due to removal of fine particles from their surfaces. Friability generally reflects poor cohesion of tablet ingredients. Standard devices have been fabricated to measure friability such instruments, marketed as friability test apparatus' or 'friabilator'. The friability (F) of sample of 10 tablets measured using Roche friabillator ( $25 \mathrm{rpm}$ for 4 minutes). Tablets were re-weighed after removal of fines (de-dusted) and the percentage of weight loss were calculated. It is expressed in (\%). Friability below $1 \%$ is acceptable.

$$
\% F=\left[\frac{W_{1}-W_{2}}{W_{1}}\right] \times 10 \ldots \ldots \ldots .7
$$

\section{Wetting time and water absorption ratio}

The wetting time of tablets can be measure using a simple procedure. A filter paper of $10 \mathrm{~cm}$ diameter was placed in a Petri dish with a $10 \mathrm{~cm}$ diameter. One milliliter of water containing amaranth, a water-soluble dye, was added to petri dish. A tablet was carefully placed on the surface of the filter paper. The time required for water to reach the upper surface of the tablet was noted as wetting time.

Water absorption ratio is determined by difference between weight of the tablet before absorption and weight of the tablet after absorption.

$$
R=\left[\frac{W_{a}-W_{b}}{W_{b}}\right] \times 100 \ldots \ldots \ldots \ldots . . .8
$$


Table 1: Composition of different batches of fast dispersing tablets of diclofenac sodium.

\begin{tabular}{|c|c|c|c|c|c|c|c|c|c|}
\hline $\begin{array}{c}\text { Ingredients (mg) } \\
\begin{array}{c}\text { Formulation } \\
\text { code }\end{array} \\
\end{array}$ & $\begin{array}{c}\text { Diclofenac } \\
\text { sodium }\end{array}$ & Crospovidone & $\begin{array}{c}\text { Sodium } \\
\text { starch } \\
\text { glycolate } \\
\end{array}$ & $\begin{array}{c}\text { Micro } \\
\text { crystalline } \\
\text { cellulose } \\
\end{array}$ & $\begin{array}{l}\text { Rasp } \\
\text { Berry }\end{array}$ & Mannitol & Talc & $\begin{array}{c}\text { Magnesium } \\
\text { stearate }\end{array}$ & $\begin{array}{c}\text { Total } \\
\text { weight } \\
\text { (mg) }\end{array}$ \\
\hline Control & 50 & - & - & 50 & 1 & 41 & 3 & 5 & 150 \\
\hline FC1 & 50 & 8 & - & 50 & 1 & 33 & 3 & 5 & 150 \\
\hline $\mathrm{FC} 2$ & 50 & 10 & - & 50 & 1 & 31 & 3 & 5 & 150 \\
\hline FC3 & 50 & 12 & - & 50 & 1 & 29 & 3 & 5 & 150 \\
\hline FS1 & 50 & - & 8 & 50 & 1 & 33 & 3 & 5 & 150 \\
\hline $\mathrm{FS} 2$ & 50 & - & 10 & 50 & 1 & 31 & 3 & 5 & 150 \\
\hline FS3 & 50 & - & 12 & 50 & 1 & 29 & 3 & 5 & 150 \\
\hline FCS1 & 50 & 8 & 8 & 50 & 1 & 25 & 3 & 5 & 150 \\
\hline FCS2 & 50 & 10 & 10 & 50 & 1 & 21 & 3 & 5 & 150 \\
\hline FCS3 & 50 & 12 & 12 & 50 & 1 & 17 & 3 & 5 & 150 \\
\hline FCS4 & 50 & 10 & 8 & 50 & 1 & 23 & 3 & 5 & 150 \\
\hline FCS5 & 50 & 10 & 6 & 50 & 1 & 25 & 3 & 5 & 150 \\
\hline FCS6 & 50 & 10 & 4 & 50 & 1 & 28 & 3 & 5 & 150 \\
\hline
\end{tabular}

Tablets are prepared in batch of 50 .

Table 2: Weight variations specifications as per U. S. P.

\begin{tabular}{|c|c|}
\hline Average weight of a tablet & $\%$ Deviation \\
\hline $80 \mathrm{mg}$ or less & 10 \\
\hline More than $80 \mathrm{mg}$ but less than $250 \mathrm{mg}$ & 7.5 \\
\hline $250 \mathrm{mg}$ or more & 5 \\
\hline
\end{tabular}

Table 3: Precompression parameters of formulation blends.

\begin{tabular}{|c|c|c|c|c|c|}
\hline Formulation code & $\begin{array}{c}\text { Bulk Density } \\
\text { (g/cc) } \pm \text { SD }\end{array}$ & Tapped Density (g/cc) \pm SD & $\begin{array}{c}\text { Angle of repose (degree) } \\
\pm \mathrm{SD}\end{array}$ & $\begin{array}{c}\text { Carr's compressibility } \\
\text { index }(\%) \pm \mathrm{SD}\end{array}$ & $\begin{array}{c}\text { Hausner's ratio } \\
\pm \text { SD }\end{array}$ \\
\hline Control & $0.65 \pm 0.5$ & $0.81 \pm 0.16$ & $38 \pm 1.01$ & $22.0 \pm 0.5$ & 1.21 \\
\hline $\mathrm{FC}_{1}$ & $0.47 \pm 0.02$ & $0.61 \pm 0.01$ & $27.4 \pm 0.2$ & $13.43 \pm$ & 1.17 \\
\hline $\mathrm{FC}_{2}$ & $0.46 \pm 0.04$ & $0.62 \pm 0.02$ & $26.1 \pm 0.2$ & 15.16 & 1.19 \\
\hline $\mathrm{FC}_{3}$ & $0.48 \pm 0.02$ & $0.56 \pm 0.05$ & $20.3 \pm 0.5$ & 14.08 & 1.27 \\
\hline FS1 & $0.46 \pm 0.03$ & $0.64 \pm 0.31$ & $21.5 \pm 0.6$ & 15.23 & 1.18 \\
\hline $\mathrm{FS} 2$ & $0.48 \pm 0.12$ & $0.53 \pm 0.02$ & $28.6 \pm 0.2$ & 14.67 & 1.26 \\
\hline FS3 & $0.45 \pm 0.15$ & $0.61 \pm 0.05$ & $27.9 \pm 0.6$ & 14.28 & 1.21 \\
\hline FCS1 & $0.44 \pm 0.01$ & $0.58 \pm 0.02$ & $26.4 \pm 0.2$ & 13.56 & 1.19 \\
\hline FCS2 & $0.48 \pm 0.06$ & $0.65 \pm 0.16$ & $23.9 \pm 0.9$ & 13.79 & 1.18 \\
\hline FCS3 & $0.46 \pm 0.02$ & $0.56 \pm 0.15$ & $25.7 \pm 0.5$ & 15.89 & 1.16 \\
\hline FCS4 & $0.42 \pm 0.06$ & $0.51 \pm 0.01$ & $24.8 \pm 0.9$ & 12.81 & 1.15 \\
\hline FCS5 & $0.41 \pm 0.51$ & $0.49 \pm 0.05$ & $22.1 \pm 0.4$ & 11.63 & 1.17 \\
\hline FCS6 & $0.40 \pm 0.09$ & $0.45 \pm 0.01$ & $20.3 \pm 0.2$ & 12.01 & 1.14 \\
\hline
\end{tabular}

\section{Drug content}

Drug content was measured by taking randomly 2 tablets per batch. An amount equivalent to $10 \mathrm{mg}$ of diclofenac sodium was dissolved in methanol, suitably diluted with $7.8 \mathrm{pH}$ phosphate buffer and filtered. The absorbance of the solutions were measured spectrophotometrically against the blank $7.8 \mathrm{pH}$ phosphate buffer at $276 \mathrm{~nm}$ using U.V spectrophotometer (Cary 60) Agilent technologies, Malaysia.

\section{Stability study}

Storing tablets at $40{ }^{\circ} \mathrm{C} \pm 2{ }^{\circ} \mathrm{C}$ and $75 \pm 5 \%$ relative humidity conducted stability study for six months. The drug content and dissolution behaviors from FDTs were tested in threemonth intervals. Each tablet was individually wrapped in a aluminum foil and packed in PVC bottle and put at above specified conditions in a heating humidity chamber $\left(40{ }^{\circ} \mathrm{C} \pm 2{ }^{\circ} \mathrm{C}\right.$ and $75 \pm 5 \%$ relative humidity) for six months. After three months of interval, tablet sample was analyzed for drug content and dissolution.

\section{In-vitro dispersion time}

Two tablets were placed in a $100 \mathrm{~mL}$ beaker containing phosphate buffer solution $\mathrm{pH} 7.8$ at $37{ }^{\circ} \mathrm{C}$. Time required to complete dispersion of tablet was observed.

\section{In-vitro disintegration time}

The process of breakdown of a tablet into smaller particles is known as disintegration. It is tested by using digital tablet disintegration apparatus (Cintex industrial corporation, Mumbai, India).

Place one tablet in each 6 tubes of the basket. Add a disc to each tube and run the apparatus using $7.8 \mathrm{pH}$ phosphate buffer maintained at $37{ }^{\circ} \mathrm{C}$ as the immersion liquid. The assembly should raise and lowered between 30 cycles per minute in the $7.8 \mathrm{pH}$ phosphate buffer.

The time in seconds taken for complete disintegration of the tablet with no palpable mass remaining in the apparatus was measured and recorded. It must be disintegrated within 3 minutes. 


\section{In-vitro dissolution studies}

In-vitro dissolution studies of the tablets were carried out in USP XXIII dissolution apparatus type II (Electro Lab, Mumbai, India) employing a paddle stirrer at $50 \mathrm{rpm}$ using $900 \mathrm{~mL}$ of $\mathrm{pH}$ 7.8 phosphate buffer at $37 \pm 0.5{ }^{\circ} \mathrm{C}$ as a dissolution medium. One tablet was used in each test. Aliquots of $5 \mathrm{~mL}$ each were withdrawn at specified time intervals $(1,3,5,10,15,30,45$ and 60 minutes.) and replaced with equal volume of fresh medium.

The withdrawn aliquots were analyzed for drug content spectrophotometrically at $\lambda_{\max } 276 \mathrm{~nm}$. Drug concentration was calculated and expressed as cumulative percent of the drug released. Results are of three determinants.

\section{RESULTS AND DISCUSSION}

Diclofenac fast dispersing tablets were prepared by direct compression method being the most simplest and economic technique. Mannitol was used as diluent to impart multidimensional benefits such as good aqueous solubility and good wetting properties that facilitating tablet breakdown as well as negative heats of solution. Crospovidone, sodium starch glycolate used as superdisintegrants leading to rapid breakdown and fast drug dissolution. To improve patient compliance (palatability) of the drug rasp berry was added in the formulation as flavoring agent.

\section{Pre-compression evaluation}

\section{FTIR spectroscopy}

FTIR analysis of pure drug and optimized formulation (FCS6) containing diclofenac sodium, crospovidone, sodium starch glycolate were shown in the Fig. 2 and Fig. 3 respectively. The spectrum of diclofenac sodium showed an intense, well defined peak, infrared band at around $1602.85 \mathrm{~cm}^{-1}(\mathrm{C}=\mathrm{C})$ and
$3203.76 \mathrm{~cm}^{-1}\left(\mathrm{COOH}\right.$ carboxylic acid) peak and $3387.00 \mathrm{~cm}^{-1}(\mathrm{~N}-$ $\mathrm{H}$ amine) peaks were observed.

Infrared spectra of optimized formulation showed the characteristic peaks of the pure drug diclofenac sodium. From the above interpretation, it is found that there is no shifting in the frequencies of above said functional groups. Hence, above result conclude that no drug and excipients interaction were found.

\section{Differential scanning calorimeter study}

The thermogram of pure drug diclofenac sodium shows endothermic peak at $288.94{ }^{\circ} \mathrm{C}$ as shown in Fig. 2, DSC thermogram of the optimized tablet formulation containing diclofenac sodium, sodium starch glycolate, crospovidone had shown peaks at $69.91{ }^{\circ} \mathrm{C}$ and $270.19{ }^{\circ} \mathrm{C}$. (Fig.3). The physical mixture of both diclofenac sodium, sodium starch glycolate, crospovidone had shown peaks at $69.91{ }^{\circ} \mathrm{C}$ and $270.19{ }^{\circ} \mathrm{C}$. There was a slight decrease in melting point so that we can conclude that no interaction occurs between drug and excipients and they are compatible.

\section{Pre compression parameters of formulation blend}

The angle of repose of the formulation blend was in the range of $20.3^{\circ}-28.6^{\circ}$, which indicates good flow of the drug but control showed poor flow property. The Carr's index, Hausner's ratios were found to be in the range of 11.63-15.89 and 1.14-1.27 indicating good compressibility and good respectively (Table 3).

\section{Post compression parameters of formulations Weight variation}

Weight variation for all the tablets is reported in the (Table 4). All tablets from each formulation passed weight variation test, as the $\%$ weight variation was within the pharmacopeia limits.

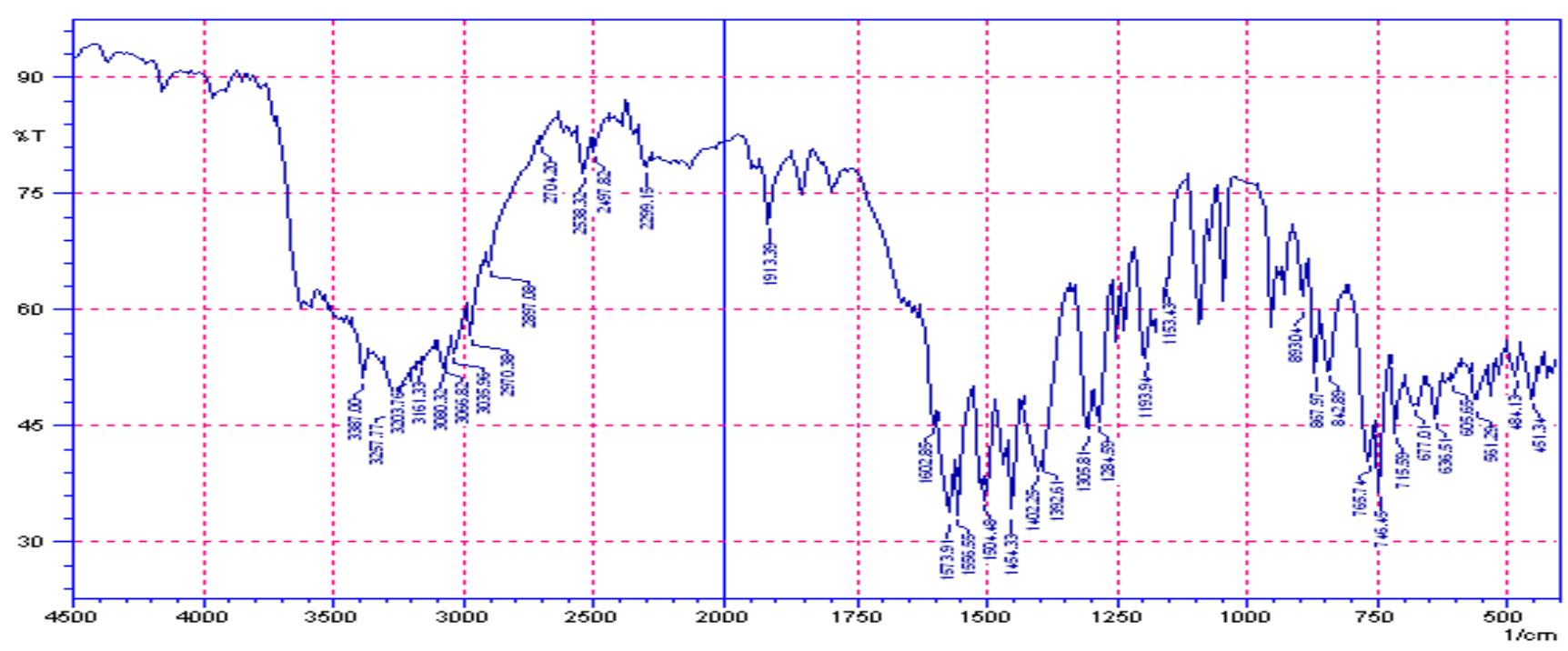

Fig. 2: FTIR spectrum of pure drug diclofenac sodium. 


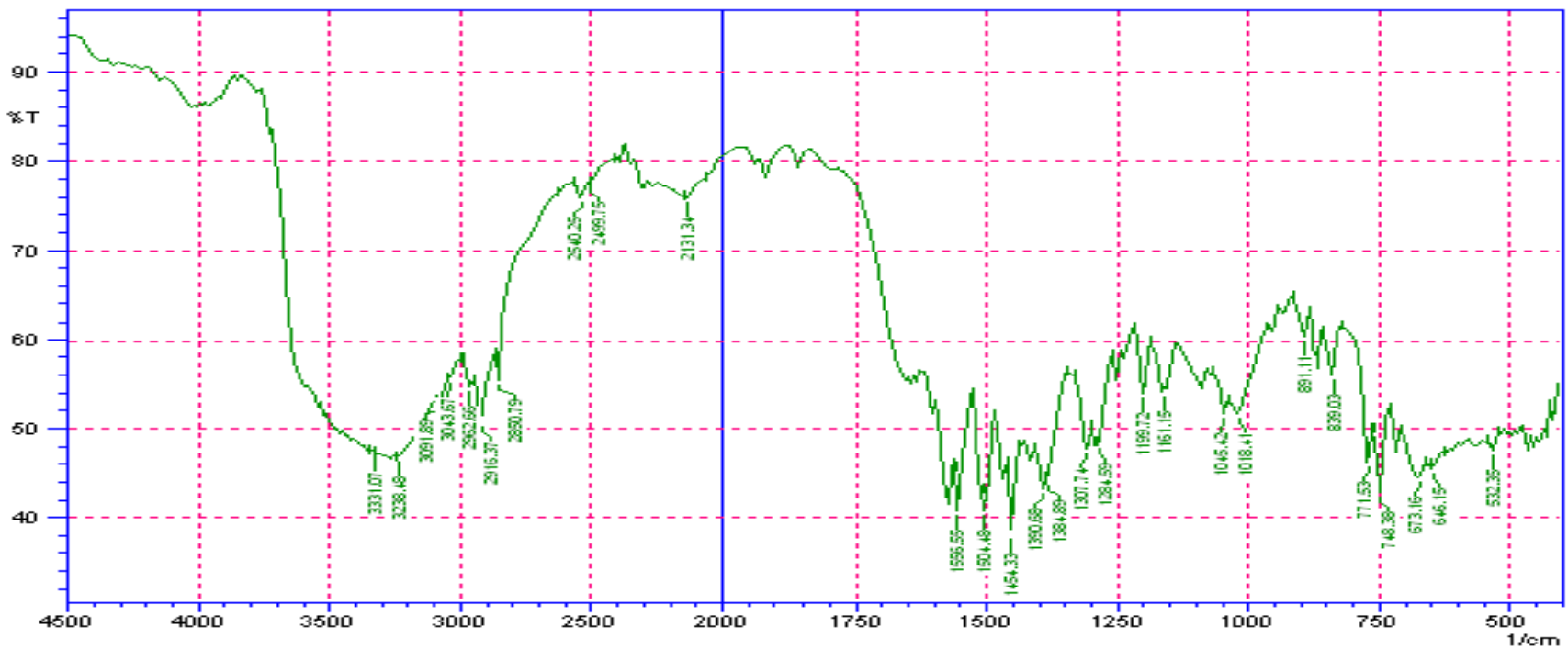

Fig. 3: FTIR spectrum of optimized formulation (FCS6).

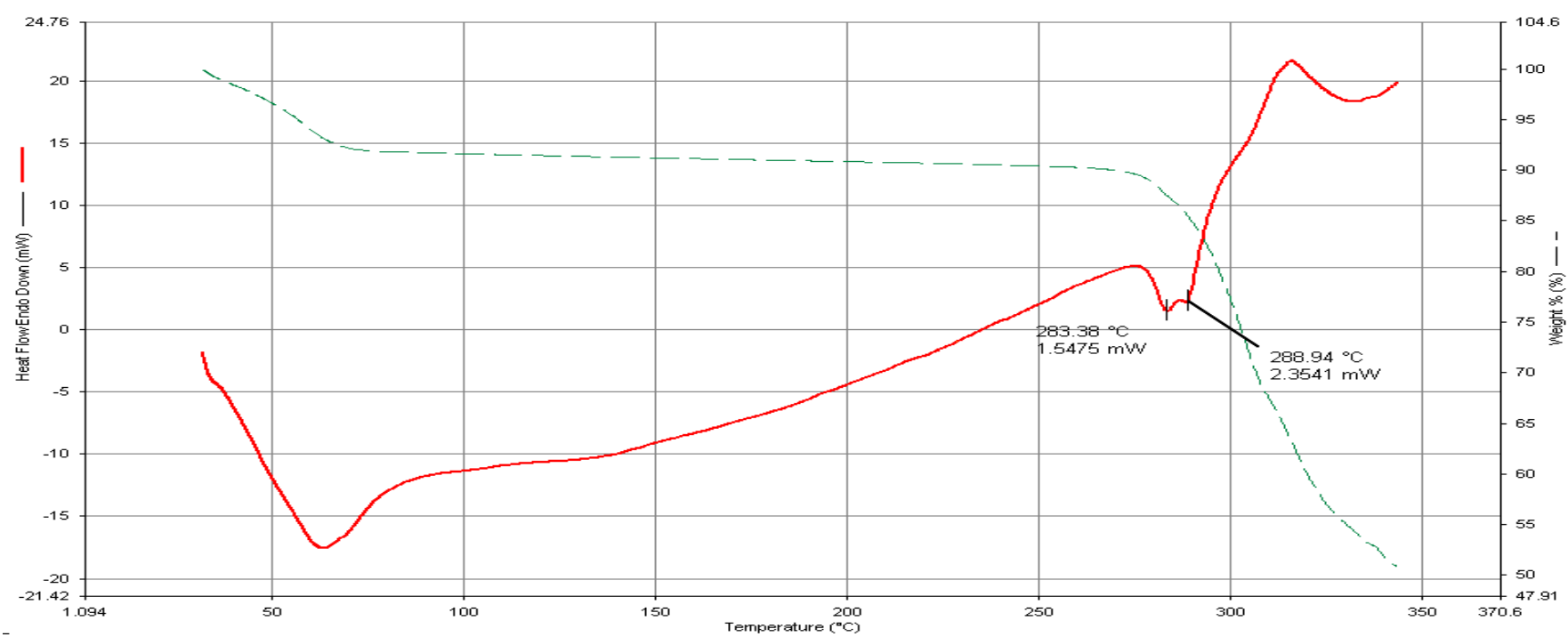

Fig. 4: DSC thermogram of pure drug diclofenac sodium.

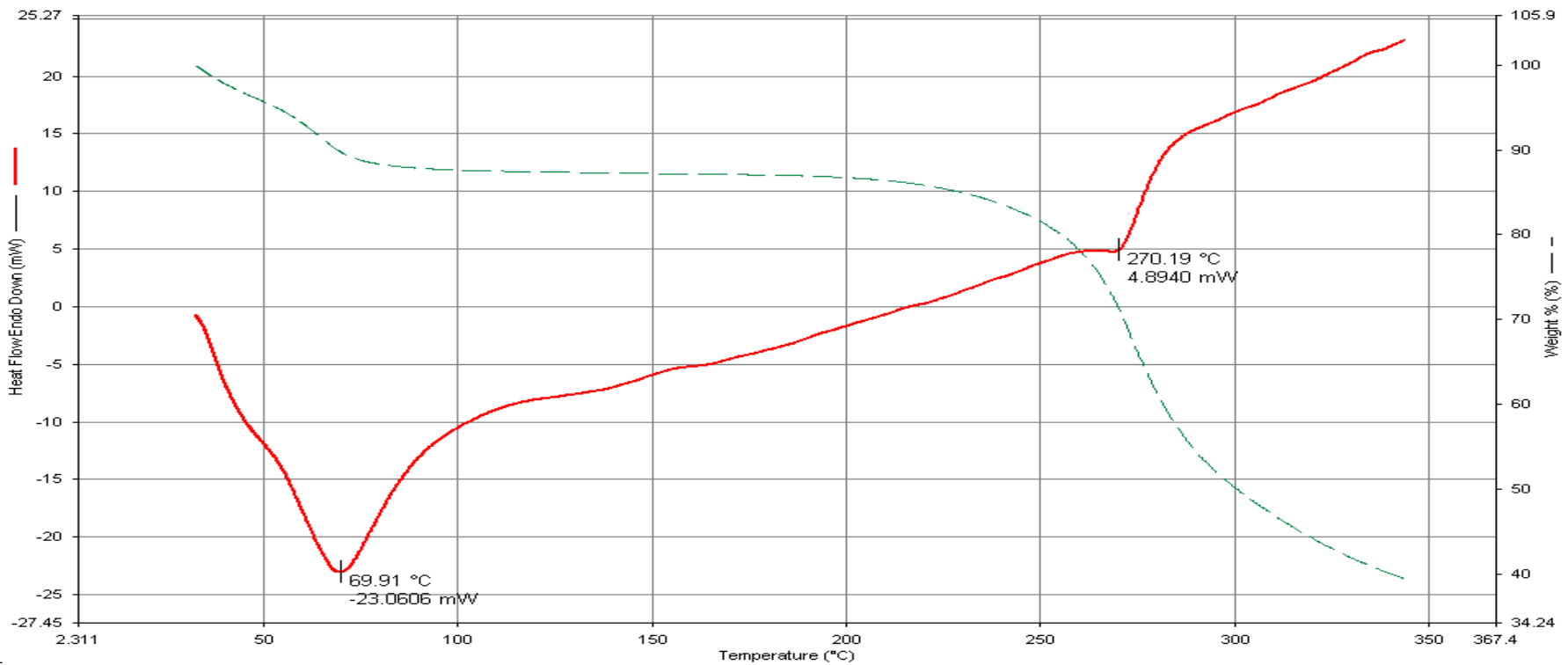

Fig. 5: DSC thermogram of optimized formulation (FCS6). 
Friability for all tablets is reported in (Table 4). Friability was determined using Roche friabilator. The friability of the formulations was found to be between $0.27-0.45$ percent and was within the official requirement (i.e. less than $1 \%$ ).

Table 4: Physical properties of diclofenac orodispersible tablets.

\begin{tabular}{ccccc}
$\begin{array}{c}\text { Formulation } \\
\text { code }\end{array}$ & $\begin{array}{c}\text { Hardness } \\
\left(\mathbf{k g} / \mathbf{c m}^{\mathbf{2}}\right)\end{array}$ & Friability & $\begin{array}{c}\text { Weight } \\
\text { variation }\end{array}$ & $\begin{array}{c}\text { Drug content } \\
(\mathbf{\%}) \\
\mathbf{\mathbf { S S D }} \mathbf{( \mathbf { n } = 3 )}\end{array}$ \\
\hline Control & 3.75 & 0.984 & 149.9 & $98.25 \pm 0.13$ \\
FC1 & 3.3 & 0.35 & 149.8 & $89 \pm 0.67$ \\
FC2 & 3.2 & 0.45 & 148.9 & $95 \pm 0.48$ \\
FC3 & 3.4 & 0.33 & 147.6 & $88 \pm 0.31$ \\
FS1 & 3.5 & 0.28 & 149.7 & $93 \pm 0.15$ \\
FS2 & 3.6 & 0.32 & 148.8 & $91 \pm 0.50$ \\
FS3 & 3.3 & 0.34 & 148.5 & $98.23 \pm 0.23$ \\
FCS1 & 3.2 & 0.27 & 149.6 & $93.21 \pm 0.41$ \\
FCS2 & 3.6 & 0.33 & 147.2 & $96.00 \pm 0.15$ \\
FCS3 & 3.4 & 0.28 & 149.9 & $89.00 \pm 0.26$ \\
FCS4 & 3.2 & 0.31 & 149.8 & $87.82 \pm 0.35$ \\
FCS5 & 3.5 & 0.29 & 148.8 & $96.47 \pm 0.44$ \\
FCS6 & 3.4 & 0.31 & 148.7 & $99.61 \pm 0.21$ \\
\hline
\end{tabular}

\section{Hardness}

Monsanto hardness tester was used to determine hardness of all the tablet formulations. The hardness was maintained to be within 3.2-3.6 kg/cm ${ }^{2}$, no variation in the hardness was found which clearly indicates that the blending was uniform (Table 4).

\section{Drug content}

The drug content values are reported in (Table 4). Assay of fast dispersing tablets was done with the help of UV-Visible spectrophotometer and the drug content was estimated. The \% drug content of all tablets was found to be between $87.82 \%$ $99.61 \%$ of diclofenac sodium, which was within acceptable limits.

\section{Wetting time}

The wetting time for all formulations within the range of 2.06- 6.01 seconds and it was represent in Fig. 6. The formulation containing $10 \mathrm{mg}$ of crospovidone and $4 \mathrm{mg}$ of sodium starch glycolate (FCS6) showed lesser wetting time of 2.06 seconds when compared to other formulations containing crospovidone and sodium starch glycolate.

\section{In vitro dispersion time}

The values of the formulations were found to be within the range of 25 seconds to 371 seconds (Fig. 6). The formulation containing $10 \mathrm{mg}(6.6 \%)$ of CP and $4 \mathrm{mg}(2.6 \%)$ of SSG (FCS6) showed a faster dispersion time of 75 seconds when compared with other formulations.

\section{In vitro disintegration time}

The In vitro disintegration time for all the formulations was reported in (Fig. 6) the disintegration test was performed using double basket disintegration apparatus. One tablet was placed in each of the six tubes of the basket and the assembly was raised and lowered between 30 cycles per minute in the $\mathrm{pH} 7.8$ phosphate buffer maintained at $37 \pm 2{ }^{\circ} \mathrm{C}$. The time in seconds taken for complete disintegration of the tablet with no palpable mass remaining in apparatus was measured and recorded the In vitro disintegration time for all twelve formulations varied from 17-360 seconds. The formula FCS6 containing CP (5.6\%), SSG (2.6\%) showed better disintegration time $(17.2 \mathrm{sec})$.

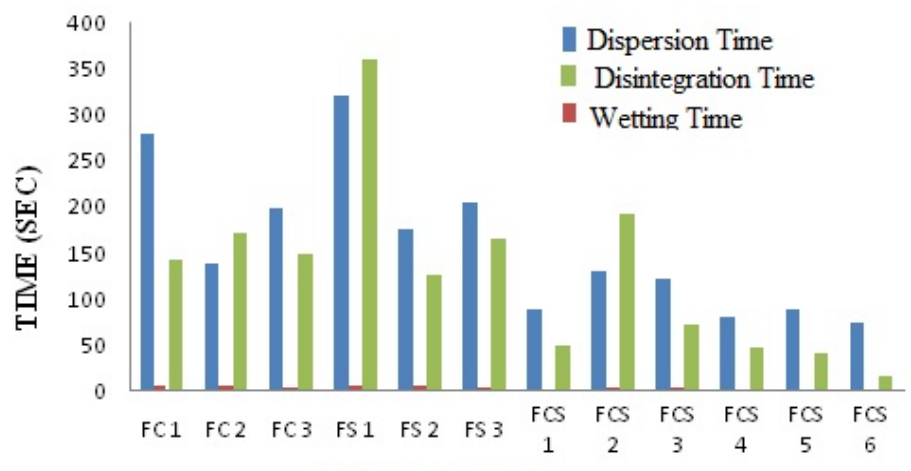

FORMULATIONS

Fig. 6: In vitro dispersion time, wetting time and disintegration time for all the formulations.

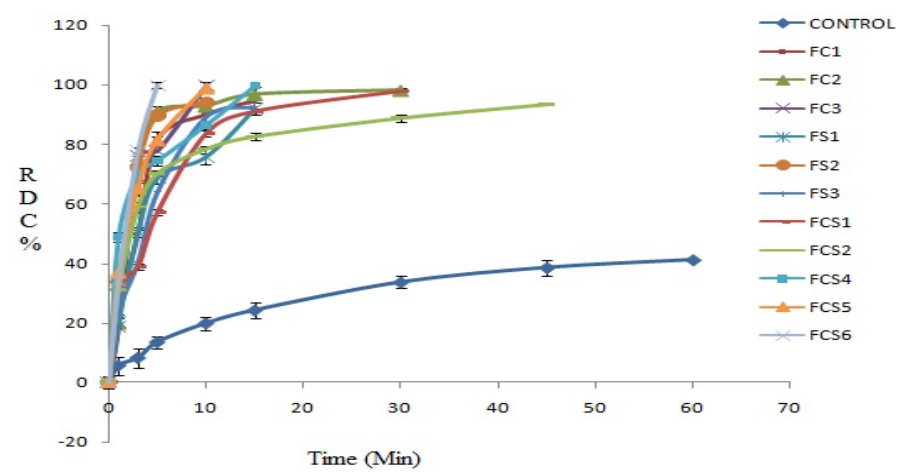

Fig. 7: Dissolution profiles of the different batches of formulations

Table 5: Dissolution parameters of diclofenac orodispersible tablets.

\begin{tabular}{ccccc}
\hline $\begin{array}{c}\text { FORMULATION } \\
\text { CODE }\end{array}$ & $\mathbf{D}_{\mathbf{5} \text { in }}$ & $\mathbf{D}_{\mathbf{1 5} \text { min }}$ & $\mathbf{t}_{\mathbf{5 0} \%(\mathbf{m i n})}$ & $\mathbf{t}_{\mathbf{9 0} \%(\mathbf{m i n})}$ \\
\hline control & 25.2 & 31.0 & 7 & 13 \\
FC1 & 81.4 & 94.5 & 2.5 & 5 \\
FC2 & 90.9 & 96.7 & 2.1 & 5 \\
FC3 & 77.7 & - & 2.0 & 8 \\
FS1 & 68.8 & 91.8 & 3.0 & 14.5 \\
FS2 & 89.7 & - & 2.2 & 5 \\
FS3 & 63.9 & 92.5 & 3.5 & 11.2 \\
FCS1 & 57.1 & 91.0 & 4.4 & 14.5 \\
FCS2 & 70.1 & 82.4 & 2.5 & 36 \\
FCS3 & 97.9 & - & 1.5 & 4.5 \\
FCS4 & 74.5 & 99.6 & 1.5 & 11.5 \\
FCS5 & 81.4 & - & 2.0 & 7.5 \\
FCS6 & 99.8 & - & 1.5 & 4.5 \\
\hline
\end{tabular}

$\mathrm{D}_{5 \min }=$ dissolution rate after 5 minutes, $\mathrm{D}_{15 \min }=$ dissolution rate after 15 minutes.

\section{In vitro dissolution study}

These fast dispersing tablets are designed to disintegrate in oral cavity and improve the bioavailability. The In vitro dissolution study was carried out using U.V Cary 60 (Agilent) apparatus. In the present investigation, 12 batches of formulations 
were prepared with two superdisintegrants alone and with different combinations. All the batches were compared with a control batch consisting without superdisintegrants.

In vitro drug release profile of the formulated batches was represented in fig. 7. Remarkable differences in the dissolution profile of different batches were observed. All formulae showed acceptable dissolution rate, where more than $75 \%$ of the label dose was dissolved within 10 minutes. These results indicate that superdisintegrant process used to prepare the orodispersible tablets enhanced the rate and extent of dissolution of diclofenac. Control batch was able to give only about $47 \%$ of drug release within 1 hour. From the In vitro dissolution data, it was found that as the concentration of superdisintegrants increased the drug release also increased. In case of crospovidone and sodium starch glycolate, as the concentration was increased, there was no significant increase in the $D_{5 \min }$ and $D_{15 \text { min }}$ values as shown in the table 5. Among the different batches of formulations FCS6 batch showed highest dissolution rate where around $90 \%$ of the label dose was dissolved within 4.5 minutes; this may be due to the combination effect of faster swelling with an increase in the concentration of the superdisintegrants and due to easy break down of particles and rapid absorption of drug into dissolution medium, thus improve the dissolution. When compared with other batches containing the single or combination of superdisintegrants, the order of In vitro drug release was obtained in the following manner.

\section{FCS6 > FCS3 $>$ FC2 $>$ FS2}

The probable reason for delayed disintegration time and dissolution rate for FCS3, FC2, FS2 batches might be the slow water uptake and gelling tendency of those super disintegrants. In terms of overall parameters the optimized formula was subjected to accelerated stability studies at $40{ }^{\circ} \mathrm{C} \pm 2{ }^{\circ} \mathrm{C}$ and $75 \pm 5 \% \mathrm{RH}$ for six months with three months intervals represented in Table 6. There is no significant change in drug content at 3 months and 6 months. The results for dissolution of optimized formulation show no appreciable change upto 6 months of accelerated stability studies illustrated in fig. 8 .

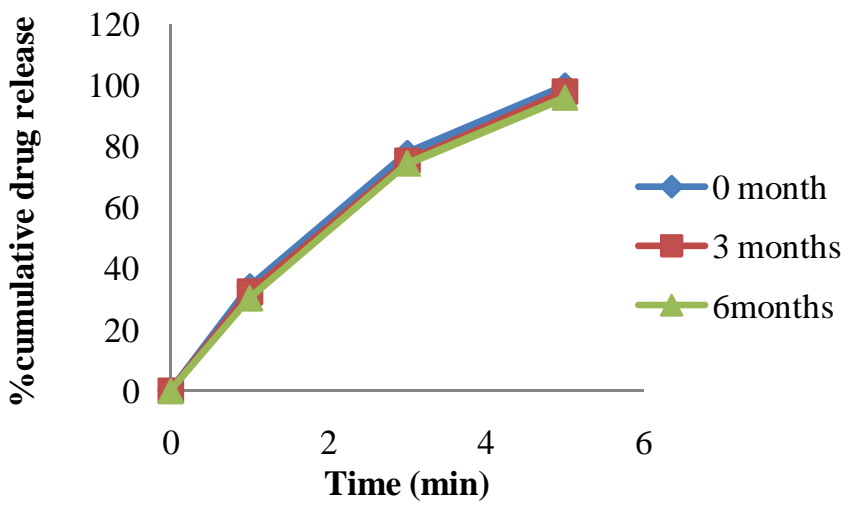

Fig. 8: Stability study of optimized formulation (FCS6).
Table 6: Drug content study of optimized formulation (FCS6) at $40{ }^{\circ} \mathrm{C} \pm 2{ }^{\circ} \mathrm{C}$ and $75 \pm 5 \%$ relative humidity.

\begin{tabular}{ccccc}
\hline $\begin{array}{c}\text { Optimized } \\
\text { formulation }\end{array}$ & Evaluation & 0 month & 3 months & 6 months \\
\hline FCS6 & $\begin{array}{c}\text { Drug } \\
\text { content }\end{array}$ & $99.61 \pm 0.19$ & $98.15 \pm 0.15$ & $97.07 \pm 0.09$ \\
\hline
\end{tabular}

\section{CONCLUSION}

Fast dispersing tablets are unique solid dosage forms mainly useful for paediatric and geriatric patients owing to their fast dispersion and disintegrating properties. There is an increasing demand for fast dissolving dosage forms as an effective alternative for emergency therapy. Diclofenac sodium is widely used Non Steroidal Anti-inflammatory drug for rheumatoid arthritis, inflammation and pain relief. Fast dispersing tablets of diclofenac sodium is an useful approach for pain management and a feasible alternative to the available conventional immediate release dosage form (Voltarin $\left.{ }^{\circledR}\right)$. Optimized formula FCS6 $(6.6 \%$ of crospovidone and $2.6 \%$ of sodium starch glycolate) of prepared fast disappearing tablets of diclofenac sodium showed improved drug release characteristics, better bioavailability (by passing first pass effect due to absorptive surface area of buccal cavity) and promising stability profile.

\section{ACKNOWLEDGEMENT}

The authors are greatly thankful to Mr.G.Maheswara sastry and P.Satish for their unlimited help during the preparation of this manuscript. Besides we would like to grateful to all the staff members of pharmaceutical technology department in the Maharajah's college of pharmacy for their efforts to facilitate us in using the necessary instruments, equipment and materials during the entire course of this research work.

\section{REFERENCES}

Agarwal V, Mishra B. Design, development, and biopharmaceutical properties of buccoadhesive compacts of pentazocine. Drug Dev Ind Pharm, 1999; 25:701- 709.

Alhusban F, Mohammed AR. Novel zero-saccharide orally disintegrating tablets. Eur. J. Pharm. Sci, 2011; 9:15-17.

Avery SW, Dellarosa DM. Approaches to treating dysphagia in patients with brain injury. Am J Occup Ther, 1994; 48:235-239.

Battu SK, Repaka MA, Majumdar S, Rao YM. Formulation and evaluation of rapidly disintegrating fenoverine tablets: Effect of superdisintegrants. Drug Dev Ind Pharm. 2007; 33:1225-32.

Chang RK, Guo X, Burnside BA, Cough RA. Fast dissolving tablets. Pharm Technol, 2000; 24:52Y58.

Chien YW. 1992. Oral drug delivery and delivery systems. In: Swarbrick J, ed. Novel drug delivery systems. 2nd rev ed. New York: Marcel Dekker Inc139- 172.

Travers DN. 1986. Powder flow and compaction. In: Carter SJ, ed. Cooper and Gunn's tutorial pharmacy. New Delhi: CBS publishers and distributors 211-233.

European Directorate for Quality of Medicines (www.pheur.org.), Pharmeuropa, 1998, 10(4), 547.

Burke A, Emer- Smyth, Garett A, Gerald F, 2006. Analgesic antipyretic agents: pharmacotherapy of gout. In: Bruton LL, ed. The pharmacological basis of therapeutics. Newyork: McGrawHill publishing division 671-715. 
Harmon TM. 2014. Orally disintegrating tablets: A valuable life a cycle management strategy. [ONLINE] Available at http://www.PharmaceuticalCommerce.com. [Accessed on 6 February 2014].

Indurwade NH, Rajyaguru TH, Nakhat PD. Novel approachFast dissolving tablets. Indian drugs 2002; 39:405-9.

Frishman WH, 2001. Principles of Clinical Pharmacology Relevant to Cardiology, In: Katzung BG, ed. Basic and clinical pharmacology. New York, McGraw-Hill 1217.

Kaushik D, Dureja H, Saini TR. Mouth dissolving tablets. Indian drugs.2014; 41:187-192.

Kearny P. 2002. The Zydis oral Fast-Dissolving dosage forms, in: Rathbone, Hadgraft,Roberts, ed. Modified- Release Drug Delivery Technology, Marcel Dekker 191-201.

Lindgren S, Janzon L. Dysphagia. Prevalence of swallowing complaints and clinical findings. Med Clin North Am. 1993; 77:3 -5.

Harmik S, Yasmin S, Roop KK. Taste masking technologies in oral pharmaceuticals: recent developments and approaches. Drug Dev.Ind.Pharm 2004; 30:429-448.
Sweetman SC, 2002. Martindale: the complete drug reference. The Pharmaceutical Press. London 2483.

Takeuchi.H, Nagira S, Yamamoto H, Kawashima Y. Die wall pressure measurement for evaluation of compaction property of pharmaceutical materials. Int J Pharm,2004; 274:131-138.

US Food \& Drug Administration. CDER Data Standard Manual. 2003; 24.

\section{How to cite this article:}

Ranjit Prasad Swain, Nagamani Ragolu, Satyajit Panda. Formulation, In vitro Characterization and Stability Studies of fast Dispersing Tablets of Diclofenac Sodium. J App Pharm Sci, 2015; 5 (07): 094-102 